\title{
Properties of a New Group of Alkalophilic Bacteria
}

\author{
By J. M. GEE, B. M. LUND,* G. METCALF AND J. L. PEEL \\ A.R.C. Food Research Institute, Colney Lane, Norwich NR4 $7 U A$
}

(Received 3 August 1979)

Five strains of a new alkalophilic bacterium have been isolated from potato-processing effluent. These strains are Gram-positive, non-sporing, motile rods which form an orange, cell-bound pigment and are capable of growth in aerobic or anaerobic conditions at a $\mathrm{pH}$ up to 11.5 and between 7 and $43{ }^{\circ} \mathrm{C}$. For one representative strain the highest growth rate occurred in the $\mathrm{pH}$ range 8 to 10.5 and the minimum doubling time observed was 27 min at approximately $38^{\circ} \mathrm{C}$. With glucose as substrate, lactate, acetate and formate were major end-products, the proportions depending on cultural conditions.

\section{INTRODUCTION}

Previous authors have described several strains of bacteria which grow optimally in alkaline media. Most of these are species of Bacillus (Vedder, 1934; Chislett \& Kushner, 1961; Wiley \& Stokes, 1962; Boyer et al., 1973; Ohta et al., 1975; Kitada \& Horikoshi, 1976; Nakamura \& Horikoshi, 1976; Akiba \& Horikoshi, 1976; Ikura \& Horikoshi, 1977) but there are also reports of alkalophilic strains of Micrococcus (Akiba \& Horikoshi, 1976), Pseudomonas (Hale, 1977), Clostridintm and a possible coryneform bacterium (Souza et al., 1974; Souza \& Deal, 1977) and a photosynthetic bacterium, Ectothiorhodospira sp. (Grant et al., 1979).

The use of sodium hydroxide in lye peeling of potatoes produces alkaline effluents in processing factories and this paper concerns a group of novel, alkalophilic bacteria isolated from such an effluent. These bacteria are similar in some respects to the unidentified bacterium, A-1, of Souza \& Deal (1977), but differ from it in several important properties.

\section{METHODS}

Culture media. PPYG medium, used for isolation and maintenance of the alkalophilic bacteria, contained $\left(\mathrm{g} \mathrm{I}^{-1}\right.$ ): peptone (Difco), 5 ; yeast extract (Difco), $1 \cdot 5$; glucose, $5 ; \mathrm{Na}_{2} \mathrm{HPO}_{4} .12 \mathrm{H}_{2} \mathrm{O}, 1 \cdot 5 ; \mathrm{NaCl}, 1 \cdot 5 ; \mathrm{MgCl}_{2}$. $6 \mathrm{H}_{2} \mathrm{O}, 0 \cdot 1 ; \mathrm{Na}_{2} \mathrm{CO}_{3}, 5 \cdot 03$. Solutions of the glucose and the $\mathrm{Na}_{2} \mathrm{CO}_{3}$ were sterilized separately by autoclaving. The final $\mathrm{pH}$ of the freshly prepared medium was $10 \cdot 5$ to $11 \cdot 0$. This medium was solidified when required by addition of New Zealand agar at $15 \mathrm{~g} \mathrm{t}^{-1}$. YG medium and TSYG medium were used for growth of cultures with pH control. YG medium contained $\left(\mathrm{g} \mathrm{l}^{-1}\right)$ : yeast extract (Difco), 2.5 ; glucose, $5 ; \mathrm{Na}_{2} \mathrm{CO}_{3}, 1 \cdot 1 ; \mathrm{NaCl}, 1 ; \mathrm{MgSO}_{4} .7 \mathrm{H}_{2} \mathrm{O}, 0 \cdot 06$. Solutions of the glucose, $\mathrm{MgSO}_{4}$ and $\mathrm{Na}_{2} \mathrm{CO}_{3}$ were sterilized separately by autoclaving. TSYG medium contained $\left(\mathrm{gl}^{-1}\right)$ : tryptone (Difco), 5 ; Soytone (Difco), 5 ; yeast extract (Difco), 5; glucose, 5. The incubation temperature was $25^{\circ} \mathrm{C}$ unless otherwise stated.

Bacteria. Strains BL77/1 to BL77/5 were isolated at $20^{\circ} \mathrm{C}$ from the effluent of a potato-processing factory by enrichment in PPYG medium followed by plating on PPYG agar. The isolates were purified by repeated plating on PPYG and Heart Infusion agar (Difco). Isolate BL77/2b occurred as a non-pigmented variant of BL77/2. Brevibacterium linens NCIB 8546 was included as a reference strain in some of the work.

Morphology. The description of colony morphology was based on cultures grown on PPYG agar for $4 \mathrm{~d}$. Gram stains were made on $24 \mathrm{~h}$ cultures using Jensen's modification (Cruickshank, 1965) and were decolor- 
ized with acetone. Smears of Streptococcus faecalis and Escherichia coli grown in Heart Infusion medium for $24 \mathrm{~h}$ were used as controls. Spore stains using Schaeffer \& Fulton's method (Cowan, 1974) were made on cultures grown on PPYG agar and on Heart Infusion agar for up to $8 \mathrm{~d}$. Motility and the arrangement of flagella were observed in $18 \mathrm{~h}$ cultures on PPYG agar. After incubation, a small amount of the growth was carefully added to a few millilitres of distilled water, the bacteria were negatively stained using an aqueous solution of uranyl acetate $(2 \%, \mathrm{w} / \mathrm{v} ; \mathrm{pH} 4.5)$ and examined under an electron microscope (AEI 801, operating at $60 \mathrm{kV}$ ).

Oxidase and catalase. Tests for oxidase (Kovacs' method) and catalase were made as described by Cowan (1974) on cultures grown for 2 and $3 \mathrm{~d}$, respectively, on PPYG agar.

Oxidative/fermentative metabolism of glucose. The medium of Hugh \& Leifson (1953) was modified by adding yeast extract (Difco, $\left.1 \mathrm{~g}^{-1}\right)$, substituting $o$-cresol red $\left(0.01 \mathrm{~g} \mathrm{l}^{-1}\right)$ for bromothymol blue and adjusting the initial $\mathrm{pH}$ to $9 \cdot 5$; results were recorded after incubation for up to $7 \mathrm{~d}$.

Production of acid from carbohydrates. The basal medium contained $\left(\mathrm{g} \mathrm{l}^{-1}\right)$ : peptone (Difco), 2 ; yeast extract (Difco), $1 ; \mathrm{K}_{2} \mathrm{HPO}_{4}, 0.3 ; o$-cresol red, 0.01 ; the $\mathrm{pH}$ was adjusted either to 8.0 or to 9.5. The appropriate carbohydrates were added as filter-sterilized solutions to the sterilized basal medium to give a final concentration of $5 \mathrm{~g} \mathrm{l}^{-1}$. The media were distributed into $10 \mathrm{ml}$ volumes in test tubes. Results were recorded after incubation for $21 \mathrm{~d}$.

Ability to use ammonia and nitrate as nitrogen sources. The basal medium contained $\left(\mathrm{g} \mathrm{l}^{-1}\right)$ : glucose, 5 ; $\mathrm{K}_{2} \mathrm{HPO}_{4}, 0.5 ; \mathrm{MgSO}_{4} .7 \mathrm{H}_{2} \mathrm{O}, 0.2 ; 0.05 \mathrm{M}-\mathrm{NaHCO}_{3} / \mathrm{Na}_{2} \mathrm{CO}_{3}$ buffer $\mathrm{pH} 9.5$; and the following trace metals (mg l-1): $\mathrm{CaCl}_{2}, 15 ; \mathrm{FeSO}_{4} \cdot 7 \mathrm{H}_{2} \mathrm{O}, 10 ; \mathrm{CuSO}_{1} \cdot 5 \mathrm{H}_{2} \mathrm{O}, 2 ; \mathrm{ZnSO}_{4} \cdot 7 \mathrm{H}_{2} \mathrm{O}, 2 ; \mathrm{MnSO}_{4} \cdot \mathrm{H}_{2} \mathrm{O}, 1 \cdot 5 ; \mathrm{CoCl}_{2} \cdot 6 \mathrm{H}_{2} \mathrm{O}$, $0.2 ; \mathrm{Na}_{2} \mathrm{MoO}_{4}, 0 \cdot 2$. The effect on growth of adding the following supplements $\left(\mathrm{g} \mathrm{l}^{-1}\right)$ singly and in combination was tested: $\mathrm{NH}_{4} \mathrm{Cl}, 1 \cdot 0 ; \mathrm{KNO}_{3}, 1 \cdot 9$; vitamin-free Casamino acids (Difco-Bacto), 3.7, plus tryptophan, $0 \cdot 185$, and cysteine. $\mathrm{HCl}, 0 \cdot 185$; yeast extract (Difco), 0.01 or 0.05 . A solution of the $\mathrm{K}_{2} \mathrm{HPO}_{4}$ and $\mathrm{MgSO}_{4}$. $7 \mathrm{H}_{2} \mathrm{O}$ was sterilized by autoclaving. Solutions at 4 to 40 times the final concentration of the $\mathrm{NaHCO}_{3} / \mathrm{Na}_{2} \mathrm{CO}_{3}$ buffer, of the trace metals and of the remaining components were sterilized separately by filtration. The inoculum was prepared by centrifuging an $18 \mathrm{~h}$ culture in PPYG medium and resuspending the sediment in an equal volume of fresh basal medium. Two drops $(0.07 \mathrm{ml})$ were used to inoculate $50 \mathrm{ml}$ quantities of medium in $250 \mathrm{ml}$ flasks. Incubation was on a rotary shaker at $150 \mathrm{rev}$. $\mathrm{min}^{-1}$, samples were withdrawn after 24 and $48 \mathrm{~h}$ and the extent of growth was measured by the absorbance of cultures at $680 \mathrm{~nm}$.

Reduction of nitrate. The medium contained $\left(\mathrm{g} \mathrm{l}^{-1}\right)$ : peptone (Difco), 2 ; yeast extract (Difco), $1 ; \mathrm{K}_{2} \mathrm{HPO}_{4}$, 0.3 ; glucose, $2 \cdot 5 ; \mathrm{KNO}_{3}, 1$. The $\mathrm{pH}$ was adjusted either to 8.0 or to 9.5 and $10 \mathrm{ml}$ quantities of the medium were distributed into test tubes. After incubation for $3 \mathrm{~d}$ and for $12 \mathrm{~d}$, samples were removed to test for reduction of nitrate using method 1 of Cowan (1974).

Ability to hydrolyse polymers. Two basal media were used to test for hydrolysis of polymers at $\mathrm{pH} 7 \cdot 5$ and 11. Basal medium 1 contained ( $\left.\mathrm{g} \mathrm{l}^{-1}\right)$ : peptone (Difco), 5; yeast extract (Difco), $1.5 ;$ glucose, $1 ; \mathrm{NaCl}$, $1.5 ; \mathrm{MgCl}_{2} \cdot 6 \mathrm{H}_{2} \mathrm{O}, 0 \cdot 1 ; 0.05 \mathrm{M}-\mathrm{K}_{2} \mathrm{HPO}_{4} / \mathrm{KH}_{2} \mathrm{PO}_{4}$ buffer $\mathrm{pH} 7.5$; agar (Difco), 15; the final pH was 7.5. Basal medium 2 was identical except that the phosphate buffer was replaced by $0.05 \mathrm{M}-\mathrm{Na}_{2} \mathrm{CO}_{3}$ and the final pH was 11. Substrates were incorporated at the concentrations given below; plates were inoculated with a single streak of the organism and incubated for $5 \mathrm{~d}$. Breakdown of potato starch (BDH, $10 \mathrm{~g} \mathrm{l}^{-1}$ ) was detected by flooding plates with a 1 in 5 dilution of Lugol's iodine solution. Breakdown of sodium carboxymethylcellulose (BDH, $\left.5 \mathrm{~g} \mathrm{I}^{-1}\right)$ and of pectin NF $\left(5 \mathrm{~g} \mathrm{l}^{-1}\right)$ in the presence of $\mathrm{CaCl}_{2}\left(1 \mathrm{mg} \mathrm{l}^{-1}\right)$ were detected by flooding plates with a $1 \%(\mathrm{w} / \mathrm{v})$ aqueous solution of hexadecyltrimethylammonium bromide (Hankin \& Anagnostakis, 1977; Hankin et al., 1971). Breakdown of dextran was investigated by a modification of the method of Mencier (1972) on plates containing Blue Dextran 2000 (Pharmacia, $2.5 \mathrm{~g}^{-1}$ ) and Dextran 20 (Pharmacia, $\left.7 \cdot 5 \mathrm{~g} \mathrm{l}^{-1}\right)$. Breakdown of gelatin $\left(4 \mathrm{~g} \mathrm{l}^{-1}\right.$ ) was detected by flooding plates with acid mercuric chloride solution (Cowan, 1974); in the case of medium 2 at pH 11, treatment with the acid mercuric chloride solution resulted in gas formation in the medium, but zones of breakdown of gelatin could nevertheless be detected. Breakdown of tributyrin $\left(30 \mathrm{ml} \mathrm{l}^{-1}\right.$ ) (Barnes \& Impey, 1972) and casein (skim milk, $50 \mathrm{~g} \mathrm{l}^{-1}$ ) were detected by zones of clearing around the colonies, and of Tween $80\left(10 \mathrm{~g} \mathrm{l}^{-1}\right)$ by formation of opaque zones (Sierra's method; Cowan, 1974).

Sensitivity to antibiotics. Plates of Wellcotest Sensitivity Test Agar (Wellcome Reagents) pH $7 \cdot 3$ to $7 \cdot 4$ were inoculated by flooding with $1 \mathrm{ml}$ of an overnight culture of the bacteria in Trypticase Soy Broth (BBL) adjusted to an initial $\mathrm{pH}$ of 8 . After $2 \mathrm{~min}$, the excess liquid was removed by pipette and a Multodisk (Code 11-14c, Oxoid) was placed on the plate. Results were recorded after incubation for $18 \mathrm{~h}$.

Effect of $\mathrm{pH}$ on initiation of growth. The range of $\mathrm{pH}$ allowing initiation of growth was determined using TSYG medium, containing $0.05 \mathrm{M}-\mathrm{Na}_{2} \mathrm{CO}_{3}$ for $\mathrm{pH}>8 \cdot 0$, adjusted with $1 \mathrm{M}-\mathrm{HCl}, 1 \mathrm{M}-\mathrm{NaOH}$ or $5 \mathrm{M}-\mathrm{NaOH}$ to $\mathrm{pH}$ values of 6.0 to 13.0 at intervals of 0.5 or $1.0 \mathrm{pH}$ unit. Inoculated and control uninoculated flasks ( $250 \mathrm{ml}$ containing $20 \mathrm{ml}$ medium) were incubated on a rotary shaker at $25^{\circ} \mathrm{C}$ and examined daily. As soon as growth was observed, the $\mathrm{pH}$ of the control uninoculated medium was measured and recorded as the $\mathrm{pH}$ at which growth was initiated. 
Temperature range for growth. Tubes of TSYG medium adjusted to $\mathrm{pH} 9 \cdot 5$ were inoculated and incubated for up to $7 \mathrm{~d}$ in a thermal gradient incubator similar in principle to that described by Matches $\&$ Liston (1973). Growth was measured turbidimetrically using an EEL nephelometer.

Effect of $\mathrm{pH}$ and temperature on rate of growth. Most of the cultures were grown at controlled $\mathrm{pH}$ using a 500 Series II modular fermenter (L.H. Engineering Co., Stoke Poges, Bucks.) with a Pye-Ingold combination pH electrode (type 465k9HA, Pye Unicam, Cambridge). A culture volume of $800 \mathrm{ml}$ was used in a 11 vessel. Aerobic conditions were achieved by aerating at $800 \mathrm{ml} \mathrm{min}^{-1}$ with a stirrer speed of $1300 \mathrm{rev} . \mathrm{min}^{-1}$; anaerobic conditions were achieved by flushing the medium with oxygen-free nitrogen at 75 to $100 \mathrm{ml} \mathrm{min}^{-1}$ with a stirrer speed of $450 \mathrm{rev}$. $\min ^{-1}$. Foaming was controlled by automatic addition of a sterile $20 \%(\mathrm{w} / \mathrm{v})$ aqueous suspension of Silicone DC Antifoam RD emulsion (Hopkin \& Williams, Chadwell Heath, Essex) and $\mathrm{pH}$ was controlled by automatic addition of sterilized $6 \mathrm{~m}-\mathrm{NaOH}$ or $1 \mathrm{M}-\mathrm{HCl}$. Sub-ambient temperatures were obtained by circulating refrigerated water through the cold finger of the fermenter. Initial experiments (part of the aerobic curve in Fig. 2) were done under similar conditions with 51 cultures in a MF-114 microferm fermenter (New Brunswick Scientific); the results were identical with those obtained using the 500 Series II fermenter. Media wete inoculated with $1 \%(\mathrm{v} / \mathrm{v})$ of the culture volume from a $16 \mathrm{~h}$ culture at $25^{\circ} \mathrm{C}$ in shaken flasks (for aerated cultures) or in static bottles (for anaerobic cultures) grown in the same medium at an initial pH of 9.5. Samples were withdrawn from the fermenter at appropriate intervals and growth rates were determined from the change in absorbance at $680 \mathrm{~nm}$; a calibration curve relating absorbance to dry weight of cells was prepared using cells grown to the stationary phase $(24 \mathrm{~h})$ in YG medium at pH 10 and $25^{\circ} \mathrm{C}$.

Estimation of metabolic products. Samples from stationary-phase cultures were centrifuged $(18000 \mathrm{~g}$, $20 \mathrm{~min}, 5^{\circ} \mathrm{C}$ ) and the supernatant was stored at $-20^{\circ} \mathrm{C}$ prior to analysis for glucose (Werner et al., 1970), lactic acid (Elsden \& Gibson, 1954), volatile fatty acids and ethanol. Volatile fatty acids were extracted by steam distillation of acidified samples (Markham, 1942). The distillates were titrated against a standardized solution of tetrabutylammonium hydroxide using cresol red as indicator and bubbling $\mathrm{CO}_{2}$-free air through the liquid before and during titration to remove $\mathrm{CO}_{2}$, and the individual volatile fatty acids were determined as their benzyl esters by gas-liquid chromatography (Jones \& Kay, 1976). Ethanol was determined by gasliquid chromatography using a Pye 104 instrument fitted with a flame ionization detector (Pye Unicam). The stainless steel column $(0 \cdot 152 \mathrm{~m} \times 6.33 \mathrm{~mm})$ packed with Poropak $Q$ (80 to $100 \mathrm{mesh}$ ) was operated isothermally at $150{ }^{\circ} \mathrm{C}$ using argon $\left(50 \mathrm{ml} \mathrm{min}^{-1}\right)$ as the carrier gas.

Extraction and examination of pigment. A portion $(300 \mathrm{ml})$ of a culture grown in TSYG medium at $\mathrm{pH} 9 \cdot 5$ for $24 \mathrm{~h}$ was centrifuged $\left(12000 \mathrm{~g}, 30 \mathrm{~min}, 3{ }^{\circ} \mathrm{C}\right)$ and the cells were washed with $50 \mathrm{ml}$ distilled water. The pellet was resuspended in methanol and the pigment was extracted by boiling under reflux for 5 min. The cell debris was removed by centrifuging $\left(12000 \mathrm{~g}, 45 \mathrm{~min}, 3^{\circ} \mathrm{C}\right)$ and the supernatant liquid was examined spectrophotometrically and by thin-layer chromatography. For chromatography, a portion of the liquid was concentrated 10 -fold by evaporation under $\mathrm{N}_{2}$ at $50{ }^{\circ} \mathrm{C}$ and applied to plates, $0 \cdot 25 \mathrm{~mm}$ thick, of $\mathrm{MN}$ Kieselgel G (Macherey, Nagel \& Co.) previously activated at $80^{\circ} \mathrm{C}$ for $1 \mathrm{~h}$ and washed in the solvent system to be used. The plates were developed in ethanol/petroleum ether (b.p. 60 to $\left.80^{\circ} \mathrm{C}\right)(1: 4, v / v)$. For comparative purposes, pigment from Brevibacterium linens NCIB 8546 grown in TSYG medium at an initial $\mathrm{pH}$ of 9.5 was examined in the same way.

$D N A$ base ratio. Strain BL77/1 was grown in TSYG medium with aerobic conditions in a fermenter at pH 9.5 and $25^{\circ} \mathrm{C}$. DNA was extracted from cells by the method of Marmur (1961) and the mol \% GC was determined by the thermal denaturation method (Marmur \& Doty, 1962).

\section{RESULTS}

\section{Morphology}

The isolates were Gram-positive, non-sporing, motile bacteria which varied in shape from short, almost coccoid forms $1.4 \times 1 \cdot 1 \mu \mathrm{m}$ in the stationary phase to rods $3.2 \times 1 \cdot 2 \mu \mathrm{m}$ in the exponential phase (Fig. 1). Longer, distorted rods were formed during exponential growth at a $\mathrm{pH}$ higher than 10 . The flagella were peritrichous and approximately $16 \mathrm{~nm}$ diameter. Growth occurred in aerobic and in anaerobic conditions and an orange pigment was formed in colonies exposed to air (except in the case of the non-pigmented variant). Colonies grown on PPYG agar for $3 \mathrm{~d}$ at $25^{\circ} \mathrm{C}$ were circular, up to $2 \mathrm{~mm}$ diameter, lowconvex, smooth, with an entire edge, orange, opaque, butyrous, easily emulsified, undifferentiated; colonies on Heart Infusion agar differed from this description in being up to 2.5 $\mathrm{mm}$ diameter, flat, fainter orange and translucent. 

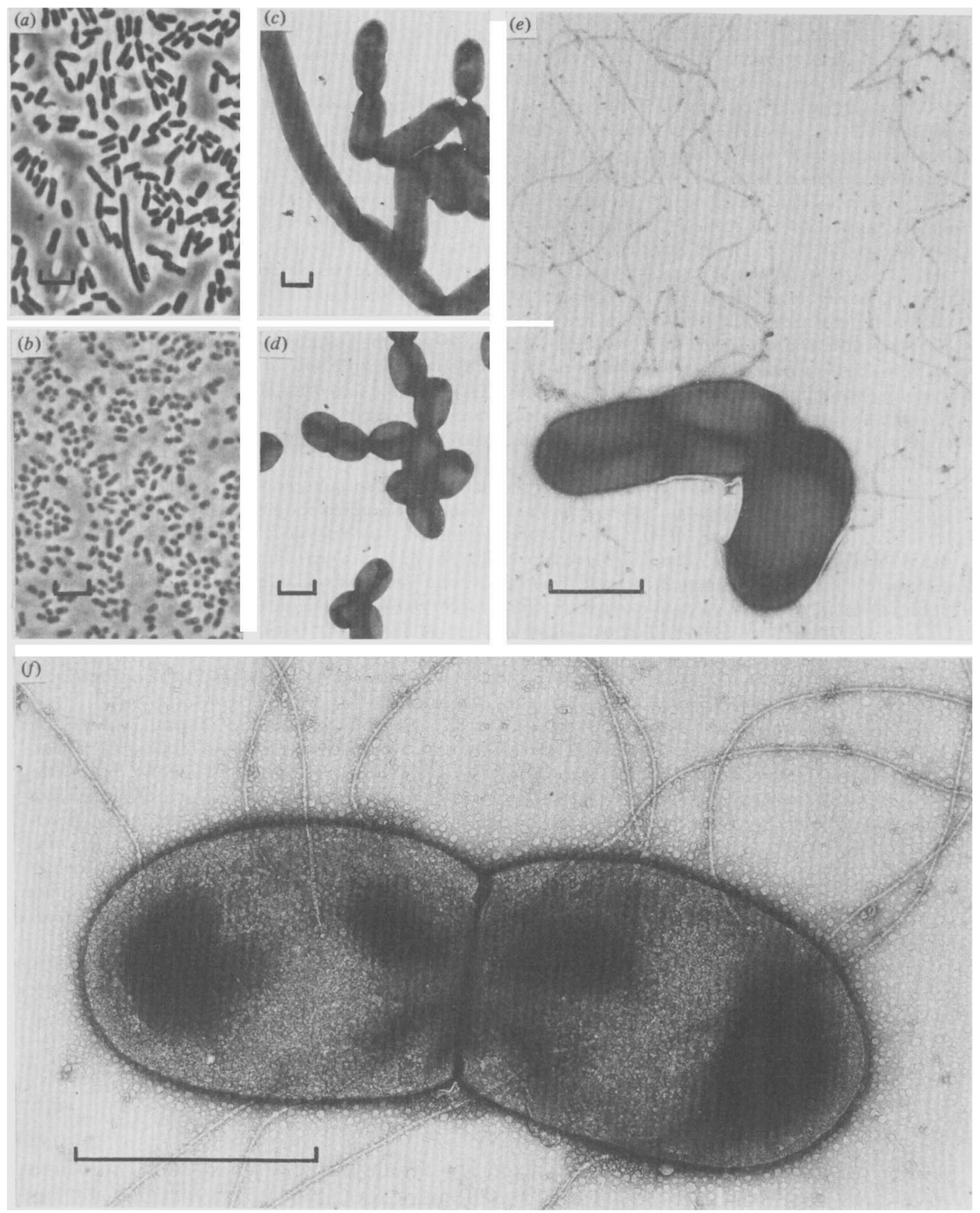

Fig. 1. Morphology of strain BL77/1.

$(a, b)$ Phase contrast photomicrographs of cells from the exponential and stationary phases of growth, respectively, in YG medium at pH 9.5. Bar markers represent $5 \mu \mathrm{m}$.

$(c-f)$ Electron micrographs of negatively stained cells: $(c)$ and $(d)$ grown as $(a)$ and $(b) ;(e)$ and $(f)$ grown on PPYG agar for $7 \mathrm{~d}$ and $24 \mathrm{~h}$, respectively. Bar markers represent $1 \mu \mathrm{m}$. 


\section{Biochemical characteristics}

The isolates were catalase-positive, oxidase-negative and metabolized glucose fermentatively. Acid was formed from galactose, glycerol, maltose, mannitol and sucrose but not from L-arabinose, dulcitol, lactose, melezitose, raffinose, rhamnose, salicin, sorbitol or xylose. Strains BL77/2, BL77/2b and BL77/4 also formed acid from fructose, and strains BL77/2b, BL77/4 and BL77/5 formed acid from salicin in medium at $\mathrm{pH} 9.5$ but not at pH 8.0. Nitrate was reduced to nitrite. Neither ammonia nor nitrate was used as sole source of nitrogen. Growth occurred in media containing Casamino acids plus tryptophan and cysteine with or without yeast extract. Starch, casein and gelatin were hydrolysed but carboxymethylcellulose, dextran, pectin, tributyrin and Tween 80 were not attacked. All strains were sensitive to chloramphenicol $(10 \mu \mathrm{g}$ per disc), erythromycin $(10 \mu \mathrm{g})$, novobiocin $(5 \mu \mathrm{g})$, oleandomycin $(5 \mu \mathrm{g})$, penicillin $\mathrm{G}(1.5 \mathrm{units} \equiv 1.0 \mu \mathrm{g})$, and tetracycline $(10 \mu \mathrm{g})$, showed slight sensitivity to streptomycin $(10 \mu \mathrm{g})$ and were resistant to sulphafurazole $(100 \mu \mathrm{g})$. The DNA from strain BL $77 / 1$ contained $55.8 \mathrm{~mol} \% \mathrm{GC}$ corresponding to a mean $T_{m}$ of $92 \cdot 3{ }^{\circ} \mathrm{C}$.

\section{Pigment}

The orange pigment did not diffuse into the medium. The intensity of the pigment varied with culture conditions and production did not occur anaerobically. It could not be extracted from cells with chloroform/methanol $(2: 1, \mathrm{v} / \mathrm{v})$ as used by Souza \& Deal (1977) and was insoluble in hexane, used by these authors to examine the absorption spectrum of pigment from strain A-1. A solution in methanol of pigment from strain BL77/1 grown at $\mathrm{pH} 9.5$ had a major absorption peak at $465 \mathrm{~nm}$ with shoulders at $490 \mathrm{~nm}$ and $438 \mathrm{~nm}$; methanol solutions of pigment from cultures grown at $\mathrm{pH} 7.5$ and 10.5 gave qualitatively similar spectra, while pigment from Brevibacterium linens had a major peak at $450 \mathrm{~nm}$ and a shoulder at $438 \mathrm{~nm}$. Thin-layer chromatography of an extract from strain BL77/1 gave a single pigmented spot with $R_{F} 0 \cdot 63$, whereas an extract from $B$. linens gave two pigmented spots with $R_{F} 0.68$ and $R_{F} 0 \cdot 71$.

\section{Effect of $\mathrm{pH}$ on growth}

In preliminary experiments using shaken flasks of TSYG medium, growth of all six isolates was observed at initial $\mathrm{pH}$ values ranging from $6 \cdot 0$ to approximately $11 \cdot 0$. The effect of $\mathrm{pH}$ was studied in more detail with strain BL77/1 in fermenters with continuous control of $\mathrm{pH}$. In YG medium at $25^{\circ} \mathrm{C}$ in aerobic or anaerobic conditions the highest growth rates were at $\mathrm{pH} 8.0$ to 10.5 and within this range there were two maxima, at $\mathrm{pH} 8.5$ and 9.5 (Fig. 2). In aerobic conditions the highest specific growth rate was $0.93 \mathrm{~h}^{-1}$ (doubling time $45 \mathrm{~min}$ ) at $\mathrm{pH} 8 \cdot 5$, while anaerobically the highest value was $0 \cdot 80 \mathrm{~h}^{-1}$ (doubling time $52 \mathrm{~min}$ ) at $\mathrm{pH}$ 9.5. On TSYG medium growth rates were similar to those on YG medium.

When the $\mathrm{pH}$ of cultures was altered rapidly from 8.0 to 10.0 or vice versa during the exponential phase, the growth rate immediately altered to that characteristic of the new $\mathrm{pH}$ indicating rapid phenotypic adaptation.

The final yield of cells on YG medium at $\mathrm{pH} 7 \cdot 0$ to $9 \cdot 0$ was slightly higher in aerobic cultures $\left(1.5\right.$ to $3.0 \mathrm{mg}$ dry wt $\left.\mathrm{ml}^{-1}\right)$ than in those grown anaerobically $\left(1.25 \mathrm{mg}\right.$ dry wt $\left.\mathrm{ml}^{-1}\right)$; yields were significantly lower when cultures were grown at the limits of the $\mathrm{pH}$ range. On TSYG medium the final yield of cells at $\mathrm{pH} 7 \cdot 0$ to $9 \cdot 0$ was much greater in aerobic cultures ( 9 to $10 \mathrm{mg}$ dry $\mathrm{wt} \mathrm{ml}^{-1}$ ) than in anaerobic cultures $\left(1.5\right.$ to $3.0 \mathrm{mg}$ dry wt $\mathrm{ml}^{-1}$ ).

\section{Effect of temperature on growth}

In preliminary experiments with strains BL77/1 and BL77/3 in tubes of TSYG medium at an initial $\mathrm{pH}$ of $9 \cdot 5$, growth occurred at temperatures of 7 to $43{ }^{\circ} \mathrm{C}$ in $7 \mathrm{~d}$. In YG medium in a fermenter with $\mathrm{pH}$ controlled at $9 \cdot 5$ the optimum temperature was approximately $38^{\circ} \mathrm{C}$ 


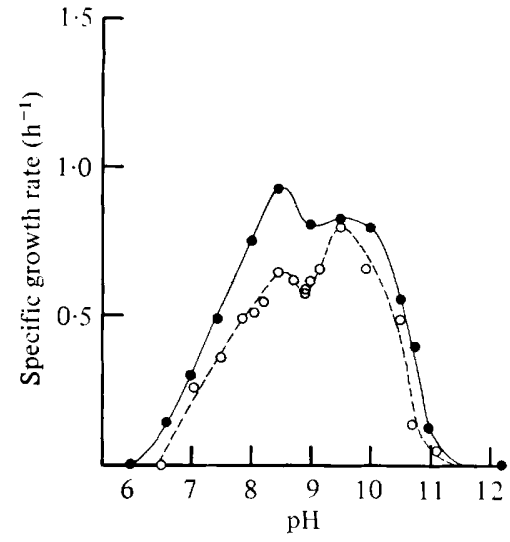

Fig. 2

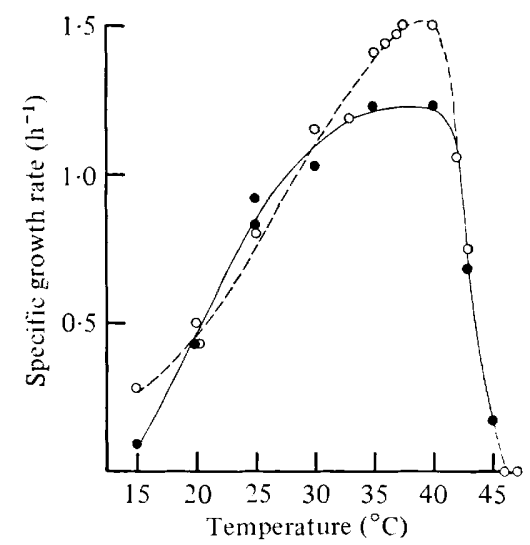

Fig. 3

Fig. 2. Effect of $\mathrm{pH}$ on the growth rate of strain BL77/1. Specific growth rate was measured in the exponential phase of growth in $\mathrm{YG}$ medium at $25^{\circ} \mathrm{C}$ with controlled pH and anaerobic (O) or aerobic $(\mathbf{O})$ conditions.

Fig. 3. Effect of temperature on the growth rate of strain BL77/1. Experimental conditions as for Fig. 2 except that the $\mathrm{pH}$ was maintained at 9.5 and the temperature was varied; anaerobic $(0)$ or aerobic (O) conditions.

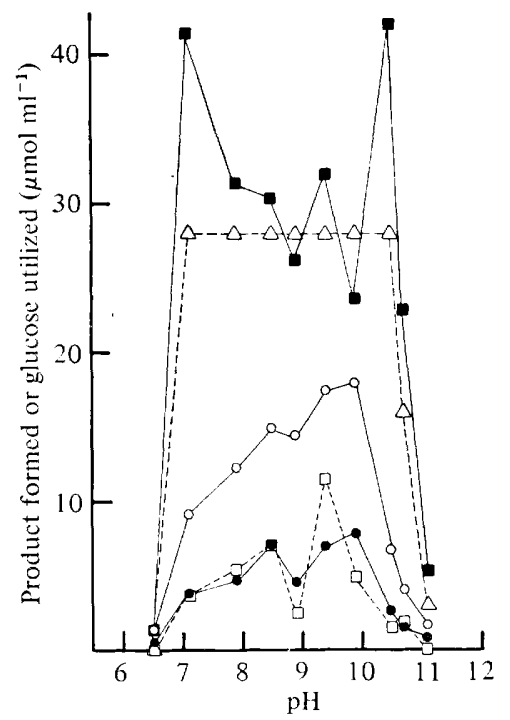

Fig. 4. Metabolic products formed from glucose by strain BL77/1. Cultures were grown anaerobically to the stationary phase at $25^{\circ} \mathrm{C}$ in $\mathrm{YG}$ medium at the constant $\mathrm{pH}$ indicated and were analysed, as described in Methods, for formate $(\circlearrowleft)$, acetate $(\odot)$, ethanol $(\square)$, lactate $(\square)$ and glucose $(\triangle)$.

in both aerobic and anaerobic cultures and the highest specific growth rate was $1.5 \mathrm{~h}^{-1}$ (doubling time $28 \mathrm{~min}$ ) in anaerobic conditions (Fig. 3).

\section{Products of glucose metabolism}

When strain BL77/1 was grown anaerobically at $25^{\circ} \mathrm{C}$ on YG medium, the glucose was fully utilized over the $\mathrm{pH}$ range $7 \cdot 1$ to $10 \cdot 5$ and the main product was lactate (Fig. 4 ) which accounted for approximately $50 \%$ of the glucose carbon between $\mathrm{pH} 8.0$ and 10.0 . Substantial amounts of formate [up to $0.65 \mathrm{~mol}(\mathrm{~mol} \text { glucose })^{-1}$ ] and of acetate were found in 
Table 1. Differences between strain BL77/1 and strain A-1 of Souza \& Deal (1977)

Both strains were Gram-positive, non-sporing, catalase-positive rods, motile by peritrichous flagella and forming an orange cell-bound pigment.

Property

Oxidase

Anaerobic growth

Reduction of nitrate

Formation of acid from:

L-Arabinose

Glycerol

Salicin

Sorbitol

Xylose

Solubility of orange pigment in hexane

Sensitivity to:

Penicillin, $1 \mu \mathrm{g}$

Tetracycline, $10 \mu \mathrm{g}$

GC content of DNA (mol \%)

Minimum doubling time ( $\mathrm{min}$ ) in aerated

culture at $\mathrm{pH} 9 \cdot 5$ :

$25^{\circ} \mathrm{C}$

$27^{\circ} \mathrm{C}$
Strain BL77/1 Strain A-1

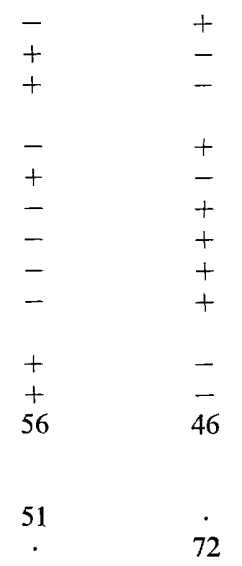

the volatile acids, and ethanol was also formed; with lactate, these products accounted for $89 \%$ of the glucose carbon at $\mathrm{pH} 9 \cdot 5$. The fate of the glucose carbon was not pursued further because of the rather high amount of yeast extract in the growth medium. As the $\mathrm{pH}$ values limiting growth were approached, the proportion of lactate increased and accounted for $75 \%$ of the glucose carbon at $\mathrm{pH} 7 \cdot 1$ and $10 \cdot 5$, while the proportion of other products decreased.

In cultures grown aerobically on YG medium, the glucose was incompletely utilized (48 to $98 \%$ ) over the $\mathrm{pH}$ range $7 \cdot 0$ to $10 \cdot 0$. Acetate accounted for approximately $40 \%$ of the glucose carbon utilized, but no ethanol was formed, while formate and lactate accounted for no more than 1 and $5 \%$, respectively, of the glucose carbon utilized. Again, as $\mathrm{pH}$ limits were approached the amount of lactate increased, e.g. at $\mathrm{pH} 11.0$ it accounted for $33 \%$ of the glucose carbon utilized.

On the more complex TSYG medium results were qualitatively similar, but among the volatile acids, the branched-chain acids (2-methylpropionate, 3-methylbutyrate and/or 2-methylbutyrate) which had been detected in traces in cultures on YG medium were formed in significant amounts. Collectively they accounted for up to $15 \%$ of the glucose carbon but were presumed to have arisen by oxidation of branched-chain amino acids in the medium.

Analysis of cultures grown at temperatures between 20 and $45^{\circ} \mathrm{C}$ and at $\mathrm{pH} 9.5$ gave similar results to those at $25^{\circ} \mathrm{C}$, both aerobically and anaerobically.

\section{DISCUSSION}

The strains described here resemble the alkalophilic bacterium A-1 described by Souza \& Deal (1977) in being Gram-positive, non-sporing rods, catalase-positive, motile by peritrichous flagella and forming an orange pigment. However, there are numerous differences between strain BL77/1 and strain A-1 (Table 1), some of the most important being the ability of the former to grow anaerobically and the differences in pigment and in DNA base ratio. The pigment from BL77/1 appeared to be more polar than that from strain A-1 as, unlike the latter, it could not be extracted with chloroform/methanol $(2: 1, \mathrm{v} / \mathrm{v})$ and did not dissolve in hexane. The absorption spectrum of pigment from BL77/1 suggested the presence of a carotenoid compound, and the pigment differed from that of Brevibacterium 
linens, for which our results agree with those of Jones et al. (1973). The mol \% GC in DNA of both BL77/1 and A-1 falls within the range reported for some groups of coryneform bacteria (Crombach, 1978), but the difference between the values for these two strains ( $56 \%$ for BL77/1, 46\% for A-1) indicates considerable dissimilarity between them. Further work is required in order to determine the taxonomic position of our isolates. Although they resemble coryneform bacteria the absence from the cell walls of mycolic acids (M. D. Collins, personal communication) indicates that they do not belong to the genus Corynebacterium.

Strain BL77/1 can be regarded as a facultative alkalophile since it grew optimally in alkaline conditions and was also capable of growth at $\mathrm{pH} 7$. Previously described facultative alkalophiles include Bacillus sphaericus and other species of Bacillus (Bornside \& Kallio, 1956; Akiba \& Horikoshi, 1976; Sunaga et al., 1976) while examples of obligate alkalophiles are B. pasteurii (Bornside \& Kallio, 1956; Wiley \& Stokes, 1962) and B. alcalophilus (Vedder, 1934; Guffanti et al., 1978). The $\mathrm{pH}$ range for optimum growth (8 to 10) and the upper limit (between 11 and 11.5) are similar to those of most of the known alkalophiles, although a $\mathrm{pH}$ optimum of 10.5 has been reported for B. alcalophilus (Guffanti et al., 1978). The occurrence of two $\mathrm{pH}$ optima is unusual and may reflect the operation of different limiting physiological systems at these $\mathrm{pH}$ values; the response of exponentially growing cultures to alteration of $\mathrm{pH}$ indicates that these two optima were not due to the presence of two genetically different variants.

The authors are grateful to Mr M. G. Hilton for determination of the DNA base ratio, to $\mathrm{Mr} \mathrm{N}$. M. King for assistance with electron microscopy and to Mr M. J. Tatton for technical assistance.

\section{REFERENCES}

Akiba, T. \& HoRIKoshI, K. (1976). Identification and growth characteristics of $\alpha$-galactosidaseproducing microorganisms. Agricultural and Biological Chemistry 40, 1845-1849.

BARnes, E. M. \& ImPEy, C. S. (1972). Some properties of the nonsporing anaerobes from poultry caeca. Journal of Applied Bacteriology 35, 241-251.

Bornside, G. H. \& Kallio, R. E. (1956). Ureahydrolyzing bacilli I. A physiological approach to identification. Journal of Bacteriology 71, 627634.

Boyer, E. W., INGLe, M. B. \& Mercer, G. D. (1973). Bacillus alcalophilus subsp. halodurans subsp.nov., an alkaline-amylase-producing alkalophilic organism. International Journal of Systematic Bacteriology 23, 238-242.

Chislett, M. E. \& Kushiner, D. J. (1961). A strain of Bacillus circulans capable of growing under highly alkaline conditions. Journal of General Microbiology 24, 187-190.

Cowan, S. T. (1974). Cowan \& Steel's Manual for the Identification of Medical Bacteria, 2nd edn. Cambridge: Cambridge University Press.

CrombacH, W. H. J. (1978). DNA base ratios and DNA hybridisation studies of coryneform bacteria, mycobacteria and nocardiae. In Coryneform Bacteria, pp. 161-179. Edited by I. J. Bousfield \& A. G. Callely. London: Academic Press.

Cruickshank, R. (editor) (1965). Medical Microbiology, 11 th edn. Edinburgh: E. \& S. Livingstone.

Elsden, S. R. \& Gibson, Q. H. (1954). The estimation of lactic acid using ceric sulphate. Biochemical Journal 58, 154-158.
Grant, W. D., Mills, A. A. \& Schofield, A. K. (1979). An alkalophilic species of Ectothiorhodospira from a Kenyan soda lake. Journal of General Microbiology 110, 137-142.

Guffanti, A. A., Susman, P., Blanco, R. \& KRULWICH, T. A. (1978). The protonmotive force and $\alpha$-aminoisobutyric acid transport in an obligately alkalophilic bacterium. Journal of Biological Chemistry 253, 708-715.

HaLe, E. M. (1977). Isolation of alkalophilic bacteria from an alkaline reservoir used in an industrial process. Proceedings of the 77th Annual Meeting of the American Society for Microbiology, abstract 150 .

Hankin, L. \& Anagnostakis, S. L. (1977). Solid media containing carboxymethylcellulose to detect $\mathbf{C}_{\mathrm{x}}$ cellulase activity of micro-organisms. Journal of General Microbiology 98, 109-115.

HANkIN, L., ZuCKER, M. \& SANDS, D. C. (1971). Improved solid medium for the detection and enumeration of pectolytic bacteria. Applied Microbiology 22, 205-209.

Hugh, R. \& Leifson, E. (1953). The taxonomic significance of fermentative versus oxidative metabolism of carbohydrates by various Gramnegative bacteria. Journal of Bacteriology 66, 24-26.

IKURA, Y. \& HoRIKosHI, K. (1977). Isolation and some properties of alkalophilic bacteria utilizing rayon waste. Agricultural and Biological Chemistry 41, 1373-1377.

JONES, D. W. \& KAY, J. J. (1976). Determination of volatile fatty acids $C_{1}-C_{6}$ and lactic acid in silage 
juice. Journal of the Science of Food and Agriculture, 27, 1005-1014.

Jones, D., Watkins, J. \& Erickson, S. K. (1973). Taxonomically significant colour changes in Brevibacterium linens probably associated with a carotenoid-like pigment. Journal of General Microbiology 77, 145-150.

Kitada, M. \& Horikoshi, K. (1976). Alkaline protease production from methyl acetate by alkalophilic Bacillus sp. Journal of Fermentation Technology 54, 383-392.

MARKHAM, R. (1942). A steam distillation apparatus suitable for micro-Kjeldahl analysis. Biochemical Journal 36, 790-791.

MARMUR, J. (1961). A procedure for the isolation of deoxyribonucleic acid from microorganisms. Journal of Molecular Biology 3, 208-218.

Marmur, J. \& Doty, P. (1962). Determination of the base composition of deoxyribonucleic acid from its thermal denaturation temperature. Journal of Molecular Biology 5, 109-118.

Matches, J. R. \& Liston, J. (1973). Temperaturegradient incubator for the growth of clostridia. Canadian Journal of Microbiology 19, 1161-1165.

Mencier, F. (1972). Méthode simple et rapide de mise en évidence des microorganismes producteurs de dextranase. Annales de l'Institut Pasteur 122, 153-157.

NAKAMura, N. \& HoRIKoshi, K. (1976). Characterization and some cultural conditions of a cyclo- dextrin glycosyltransferase-producing alkalophilic Bacillus sp. Agricultural and Biological Chemistry 40, 753-757.

Ohta, K., Kiyomiya, A., Koyama, N. \& Nosoh, Y. (1975). The basis of the alkalophilic property of a species of Bacillus. Journal of General Microbiology 86, 259-266.

SouzA, K. A. \& DeAl, P. H. (1977). Characterization of a novel extremely alkalophilic bacterium. Journal of General Microbiology 101, 103-109.

Souza, K. A., Deal, P. H., Mack, H. M. \& TurnBILL, C. E. (1974). Growth and reproduction of microorganisms under extremely alkaline conditions. Applied Microbiology 28, 1066-1068.

Sunaga, T., Akiba, T., \& Horikoshi, K. (1976). Production of penicillinase by an alkalophilic Bacillus. Agricultural and Biological Chemistry 40, 1363-1367.

VEDDER, A. (1934). Bacillus alcalophilus n.sp. Antonie van Leeuwenhoek 1, 141-147.

Werner, W., Rey, H. G. \& Wielinger, H. (1970). Über die Eigenschaften eines neuen Chromogens für die Blutzuckerbestimmung nach der GOD/ POD-Methode. Zeitschrift für analytische Chemie 252, 224-228.

WILeY, W. R. \& Stokes, J. L. (1962). Requirement of an alkaline $\mathrm{pH}$ and ammonia for substrate oxidation by Bacillus pasteurii. Journal of Bacteriology 84, 730-734. 